\title{
The effect of free glutamine and peptide ingestion on the rate of muscle glycogen resynthesis in man
}

Citation for published version (APA):

van Hall, G., van de Schoor, P. A. I., Saris, W. H. M., \& Wagenmakers, A. J. M. (2000). The effect of free glutamine and peptide ingestion on the rate of muscle glycogen resynthesis in man. International Journal of Sports Medicine, 21(1), 25-30. https://doi.org/10.1055/s-2000-10688

Document status and date:

Published: 01/01/2000

DOI:

10.1055/s-2000-10688

Document Version:

Publisher's PDF, also known as Version of record

\section{Please check the document version of this publication:}

- A submitted manuscript is the version of the article upon submission and before peer-review. There can be important differences between the submitted version and the official published version of record.

People interested in the research are advised to contact the author for the final version of the publication, or visit the DOI to the publisher's website.

- The final author version and the galley proof are versions of the publication after peer review.

- The final published version features the final layout of the paper including the volume, issue and page numbers.

Link to publication

\footnotetext{
General rights rights.

- You may freely distribute the URL identifying the publication in the public portal. please follow below link for the End User Agreement:

www.umlib.nl/taverne-license

Take down policy

If you believe that this document breaches copyright please contact us at:

repository@maastrichtuniversity.nl

providing details and we will investigate your claim.
}

Copyright and moral rights for the publications made accessible in the public portal are retained by the authors and/or other copyright owners and it is a condition of accessing publications that users recognise and abide by the legal requirements associated with these

- Users may download and print one copy of any publication from the public portal for the purpose of private study or research.

- You may not further distribute the material or use it for any profit-making activity or commercial gain

If the publication is distributed under the terms of Article $25 \mathrm{fa}$ of the Dutch Copyright Act, indicated by the "Taverne" license above, 


\title{
The Effect of Free Glutamine and Peptide Ingestion on the Rate of Muscle Glycogen Resynthesis in Man
}

\author{
G. van Hall, W. H. M. Saris, P. A. I. van de Schoor, A. J. M. Wagenmakers
}

Department of Human Biology. Maastricht University, Maastricht, The Netherlands

van Hall G, Saris WHM, van de Schoor PAI, Wagenmakers AJM. The Effect of Free Glutamine and Peptide Ingestion on the Rate of Muscle Glycogen Resynthesis in Man. Int J Sports Med 1999; 20: $25-30$

Accepted after revision: July 15, 1999

\begin{abstract}
19: tion of glutamine and of protein-carbohydrate mixtures may increase the rate of glycogen resynthesis following intense exercise. Eight trained subjects were studied during $3 \mathrm{~h}$ of recovery while consuming one of four drinks in random order. Drinks were ingested in three $500 \mathrm{ml}$ boluses, immediately after exercise and then after 1 and $2 \mathrm{~h}$ of recovery. Each bolus of the control drink contained $0.8 \mathrm{~g} \mathrm{x} \mathrm{kg}^{-1}$ body weight of glucose. The other drinks contained the same amount of glucose and $0.3 \mathrm{~g} \times \mathrm{kg}^{-1}$ body weight of 1) glutamine, 2) a wheat hydrolysate (26\% glutamine) and 3 ) a whey hydrolysate (6.6\% glutamine). Plasma glutamine, decreased by approximately $20 \%$ during recovery with ingestion of the control drink, no changes with ingestion of the protein hydrolysates drinks, and a 2-fold increase with ingestion of the free glutamine drinks. The rate of glycogen resynthesis was not significantly different in the four tests: $28 \pm 5,26 \pm 6,33 \pm 4$, and $34 \pm 3$ mmol glucosyl units $\times \mathrm{kg}^{-1}$ dry weight muscle $\times \mathrm{h}^{-1}$ for the control, glutamine, wheat- and whey hydrolysate ingestion, respectively. It is concluded that ingestion of a glutamine/carbohydrate mixture does not increase the rate of glycogen resynthesis in muscle. Glycogen resynthesis rates were higher, although not statistically significant, after ingestion of the drink containing the wheat $(21 \pm 8 \%)$ and whey protein hydrolysate $(20 \pm 6 \%)$ compared to ingestion of the control and free glutamine drinks, implying that further research is needed on the potential protein effect.
\end{abstract}

Key words: Protein hydrolysates, insulin, exercise.

Int J Sports Med 2000; 21: 25-30

(c) Georg Thieme Verlag Stuttgart · New York

ISSN 0172-4622

\section{Introduction}

Muscle glycogen from a quantitative point is the most important energy source during prolonged dynamic exercise at intensities of $>60 \% \dot{\mathrm{V}}_{2} \max$ [22]. The glycogen stores in man are relatively small $(60-80 \mathrm{~g}$ in liver and $500-700 \mathrm{~g}$ in muscle of trained athletes). The muscle glycogen concentration may fall during prolonged competitive exercise from resting values of 150 to values of $25 \mathrm{mmol}$ glucosyl units $\times \mathrm{kg}^{-1}$ wet weight muscle and lower. Depletion of the glycogen stores leads to fatigue at moderate to high exercise intensities. In events such as the Tour de France, where athletes cycle for several weeks 6 $9 \mathrm{~h}$ daily at very high energy expenditures, complete resynthesis of muscle glycogen is needed for optimal performance the next day. However, previous studies have reported glycogen resynthesis rates of $5-6 \mathrm{mmol}$ glucosyl units $\times \mathrm{kg}^{-1}$ wet weight muscle $\times h^{-1}[2,13,21,28]$ in the first $4-8$ hours after exercise, and this implies that it may take 16-20 h for complete glycogen resynthesis to occur. Such time periods are not available on most days in the Tour de France, and nutritional strategies to increase the glycogen resynthesis rate may, therefore, be important to obtain complete resynthesis.

Doubling of the rate of carbohydrate ingestion from $1.5 \mathrm{~g} / \mathrm{kg}$ body weight per $2 \mathrm{~h}$ in a drink to $3 \mathrm{~g} / \mathrm{kg}$ body weight did not further increase the glycogen resynthesis rate [13]. Similar rates of glycogen resynthesis also were obtained when $3 \mathrm{~g} / \mathrm{kg}$ body weight of glucose was taken orally every $2 \mathrm{~h}$ as a drink and in solid form and when the same amount was given by continuous intravenous infusion [21].

Two potential interventions have recently been published that may help to increase glycogen resynthesis rates following exercise. Zawadzki et al. [28] reported that addition of protein to a carbohydrate drink significantly increased glycogen resynthesis rates by $37 \%$. As higher plasma insulin concentrations were observed after ingestion of a carbohydrate/protein mixture than after carbohydrate ingestion alone, it was suggested that the insulin effect on glycogen synthase was responsible for the observed effect $[12,14]$. Varnier et al. [27] recently reported that intravenous infusion of glutamine increased muscle glycogen resynthesis rates in man. However, glycogen resynthesis was measured at sub-maximal rates in the latter study in the absence of ingested glucose. It was suggested that glutamine may directly stimulate glycogen synthase by activation of glycogen synthase phosphatase [27]. Such an effect of 
glutamine has previously also been observed in isolated hepatocytes [16] and is potentially related to an increase in cell volume [1], which again may act as a general anabolic signal in mammalian cells [10].

It cannot be ruled out that the stimulation of glycogen resynthesis by co-ingestion of protein as observed by Zawadzki et al. [28] in part is also mediated by an increase in plasma glutamine concentration, as plasma glutamine increases after ingestion of a protein containing meal [6]. The present study was designed, therefore, to investigate whether 1) the glutamine content of the protein source co-ingested with carbohydrate has an effect on glycogen resynthesis rates and whether 2) co-ingestion of free glutamine and glucose also stimulates glycogen resynthesis rates. Therefore, subjects were studied during $3 \mathrm{~h}$ of recovery from intermittent exercise, causing muscle glycogen depletion, while ingesting at regular intervals drinks containing 1) glucose only; 2) glucose and free glutamine; 3) glucose and a protein hydrolysate with a high glutamine content; 4) glucose and a protein hydrolysate with a normal glutamine content.

\section{Methods}

\section{Subjects}

Eight well trained male cyclists participated in this study. Their mean age, weight, height, and maximal one leg power output were $25 \pm 3 \mathrm{yr}, 72 \pm 3 \mathrm{~kg}, 1.83 \pm 0.03 \mathrm{~m}$ and $5.0 \pm 0.2 \mathrm{Watt} \times \mathrm{kg}^{-1}$ body weight. All subjects were healthy trained cyclists. The subjects were informed about possible risks and discomfort involved in this experiment before giving their voluntary consent to participate. The study was carried out in accordance with the Declaration of Helsinki and has been approved by the Ethical Committee of Maastricht University.

\section{Experimental protocol}

Each subject underwent four randomized experimental treatments separated by at least 7 days. Three days before the actual experiment started subjects had to perform a graded exercise test in order to determine their maximal power output $\left(W_{\max }\right)$. On the experimental days subjects reported to the laboratory at 8.30 after an overnight fast. Muscle glycogen was lowered before the treatment by intense cycle ergometer exercise. The glycogen depletion protocol was as described previously by Kuipers et al. [15]. Following a warm up period of 10 min at $50 \%$ of their $W_{\max }$ the subjects had to cycle blocks of 2 min in duration at an alternating workload of $90 \%$ and $50 \%$ of their respective $W_{\text {max. }}$. This was continued until they were not able to complete the $2 \mathrm{~min}$ at $90 \% \mathrm{~W}_{\max }$. That moment was defined as the inability to maintain a cycling speed of 60 revolutions per min. The high intensity block was then reduced to $80 \% \mathrm{~W}_{\max }$. Again the subjects had to cycle until they were unable to complete the $2 \mathrm{~min}$ at $80 \% \mathrm{~W}_{\max }$ and the intensity was reduced to $70 \% \mathrm{~W}_{\max }$. When the $70 \% \mathrm{~W}_{\max }$ could not be completed, subjects were allowed to stop. During the glycogen depletion cycle exercise the subjects were cooled with standing floor fans in a room with a constant temperature of $20^{\circ} \mathrm{C}$. Water was provided ad libitum before, during, and after the tests.

After cessation of the glycogen depietion exercise bout the subjects were allowed to take a shower, and a catheter was in- serted in an anticubital vein. Approximately $15 \mathrm{~min}$ after the end of the exercise period the pre-treatment blood sample and muscle biopsy were taken, and the first bolus of the test drink was immediately provided. Another bolus was given after 1 and $2 \mathrm{~h}$ of recovery. Each bolus of the control drink contained $0.8 \mathrm{~g} \mathrm{~kg}^{-1}$ body weight glucose (Amylum, Belgium). The other drinks contained $0.8 \mathrm{~g} \mathrm{~kg}^{-1}$ body weight glucose (Amylum, Belgium) and in addition either 1) $0.3 \mathrm{~g} \times \mathrm{kg}^{-1}$ body weight glutamine (Degussa, The Netherlands), 2) $0.3 \mathrm{~g} \times \mathrm{kg}^{-1}$ body weight of a wheat protein hydrolysate with a high glutamine content (Quest International, The Netherlands), and 3) $0.3 \mathrm{~g} \times \mathrm{kg}^{-1}$ body weight of a whey protein hydrolysate with a normal glutamine content (Quest International, The Netherlands). The protein hydrolysate with the high glutamine content was a polypeptide derived from wheat protein with a mean chain length of 11 amino acids and a glutamine content of $26 \%$. The whey protein hydrolysate had a mean chain length of 5.5 and a glutamine content of $6.6 \%$. All supplements were dissolved in water to a volume of $500 \mathrm{ml}$.

\section{Tissue collection and blood sampling}

Muscle biopsies from the quadriceps muscle were taken $15 \mathrm{~min}$ after the glycogen depletion protocol and $3 \mathrm{~h}$ thereafter from the contralateral leg. Muscle specimens were analyzed for glycogen concentration and glycogen synthase activity (active and total). Blood samples $(3 \mathrm{ml})$ were drawn before the first bolus of the test drinks and then every $30 \mathrm{~min}$. Venous blood was centrifuged to obtain plasma and immediately frozen in liquid nitrogen and analyzed for glucose, glutamine, and insulin.

\section{Analysis}

Glucose and glutamine [17] were measured enzymatically on a COBAS BIO analyzer (Roche, The Netherlands). Insulin was measured with a commercially available radio immunoassay kit (Pharmacia, Sweden).

For glycogen determination $\pm 50 \mathrm{mg}$ of wet weight muscle was heated for 3 hours at $37^{\circ} \mathrm{C}$ with $1 \mathrm{ml}$ of $1 \mathrm{M} \mathrm{NaOH} .1 \mathrm{ml}$ of ethanol was added and heated for $10 \mathrm{~min}$ at $85^{\circ} \mathrm{C}$ in sealed tubes. The solution was then kept at $4^{\circ} \mathrm{C}$ for 20 hours to precipitate glycogen and then centrifuged. $500 \mu \mathrm{l} 1 \mathrm{M} \mathrm{HCl}$ was added to the glycogen pellet and then heated for 3 hours to $100^{\circ} \mathrm{C}$ to hydrolyse the glycogen to glucosyl units. The final solution was neutralized with $1 \mathrm{M} \mathrm{NaOH}$. $150 \mu \mathrm{l}$ was used for enzymatic determination of glucose.

Glycogen synthase activity was measured by the method of Danforth [4] in which $30 \mathrm{mg}$ of muscle tissue was homogenized in SET buffer, $250 \mathrm{mM}$ sucrose, $2 \mathrm{mM}$ EDTA and $10 \mathrm{mM}$ Tris with a $\mathrm{pH}$ of 7.4. The enzyme activity was assayed at $\mathrm{pH}$ 7.4 and $30^{\circ} \mathrm{C}$ in a reaction mixture containing $60 \mathrm{mM}$ Tris, $1.2 \mathrm{mM}$ EDTA, $3 \mathrm{mM}$ mercaptoethanol, $1.2 \mathrm{mM} \mathrm{NaF}, 7.5 \mathrm{mM}$ UDP-glucose, and $1.2 \%$ glycogen. The assay was carried out in the presence and absence of $12 \mathrm{mM}$ glucose- $6-\mathrm{P}$ to measure total glycogen synthase activity $\left(\mathrm{GS}_{\text {tot }}\right)$ and active glycogen synthase activity $\left(G_{\text {act }}\right)$. The reaction was terminated by heating for $2 \mathrm{~min}$ in a boiling water bath. The denatured protein was removed by centrifugation, the supernatant solution was assayed enzymatically for UDP. UDP was measured by allowing the UDP to react with phosphoenolpyruvate in the pres- 
ence of pyruvate kinase. The formed pyruvate was measured spectrophotometrically with lactate dehydrogenase. Activities are expressed as pmol of glycosyl units from UDP-glucose incorporated into glycogen $\times \mathrm{min}^{-1} \times \mathrm{g}^{-1}$ wet weight muscle at $30^{\circ} \mathrm{C}$.

\section{Statistical analysis}

All data are presented as means \pm SE. Statistical analysis of the data was done using one way repeated measures analysis of variance (ANOVA). Differences between treatments were checked for statistical significance using the Fisher's protected least significant difference test. Statistical significance was set at $P<0.05$.

\section{Results}

Plasma glutamine decreased to a concentration approximately $20 \%$ below the first sample point 15 min after cessation of exercise (Fig. 1 a) when the control drink with only glucose was ingested. Co-ingestion of both protein hydrolysates prevented this decrease in plasma glutamine concentration. However, no difference was observed between the hydrolysate with a high and a low glutamine content, despite the 4-fold higher glutamine content in the former. Ingestion of free glutamine caused a 2-fold increase in the plasma glutamine concentration (Fig. 1 a). The amount of glutamine given as the free amino acid was 4-fold higher than the amount of glutamine ingested as the hydrolysate with the high glutamine content.

Plasma glucose concentration doubled 30 min after ingestion of the different drinks but gradually decreased thereafter to the pre-treatment concentration (Fig. $1 \mathbf{b}$ ). Ingestion of the 2nd and 3rd bolus temporarily increased plasma glucose again. Plasma insulin concentration increased after ingestion of the drinks with the highest increase present 30 min after ingestion of the drinks compared to $60 \mathrm{~min}$. The increase was much higher after the 3 rd bolus than after the 2 nd and 1 st bolus. However, the increase only reached significance with ingestion of both protein hydrolysate containing drinks $(P=0.01)$. A very rapid decrease occurred between 30 and 60 min after ingestion of the boluses, especially after ingestion of the 3 rd bolus. No differences existed in plasma insulin concentration 60 min after ingestion of the 3 rd bolus, and the concentration at that time was not significantly different from the immediate post-exercise value. Although plasma insulin concentration was significantly higher between 30 and $150 \mathrm{~min}$ of the recovery period with both protein hydrolysates compared to the control drink (Fig. 1c), no differences were observed between drinks in plasma glucose concentration (Fig. 1b). Plasma glucose concentration gradually decreased during recovery while plasma insulin concentration gradually increased.

Muscle glycogen concentration did not differ significantly before and after $3 \mathrm{~h}$ of recovery between treatments (Fig. 2). The rate of glycogen resynthesis was similar after ingestion of the control and glutamine containing drinks. However, glycogen resynthesis rates were higher, although not statistically significant, after ingestion of the drink containing the wheat$(21 \pm 8 \%)$ and whey protein hydrolysate $(20 \pm 6 \%)$ compared to ingestion of the control and free glutamine (Fig. 2). Glycogen synthase activity was the same immediately after the exercise
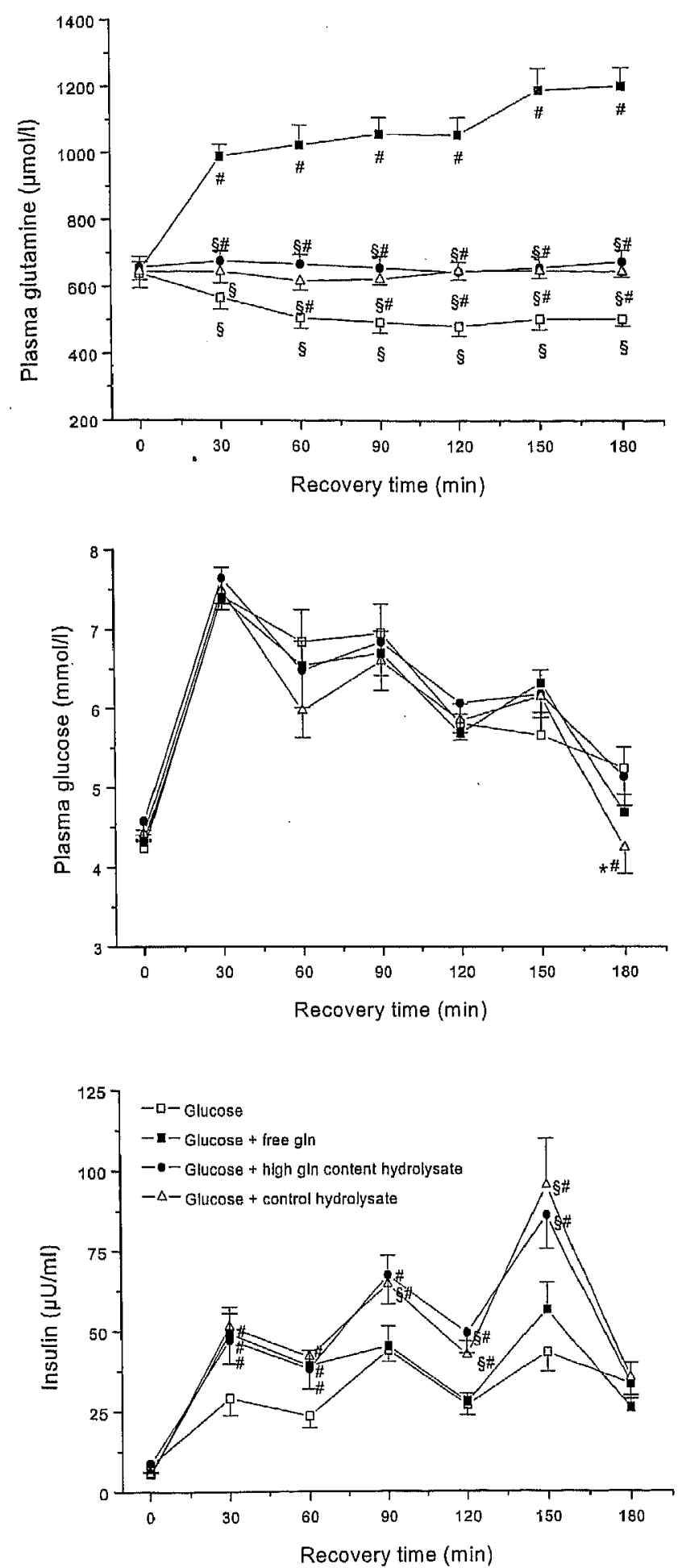

Fig. 1 Plasma glutamine, glucose, and insulin during recovery from intense exercise with oral ingestion of glucose and glutamine or protein hydrolysate. Values are means \pm SEM for 8 subjects. §Signifcant differences from glucose + free glutamine test, "significant differences from the glucose test, ${ }^{*}$ significant differences from the glucose + high glutamine content hydrolysate. 

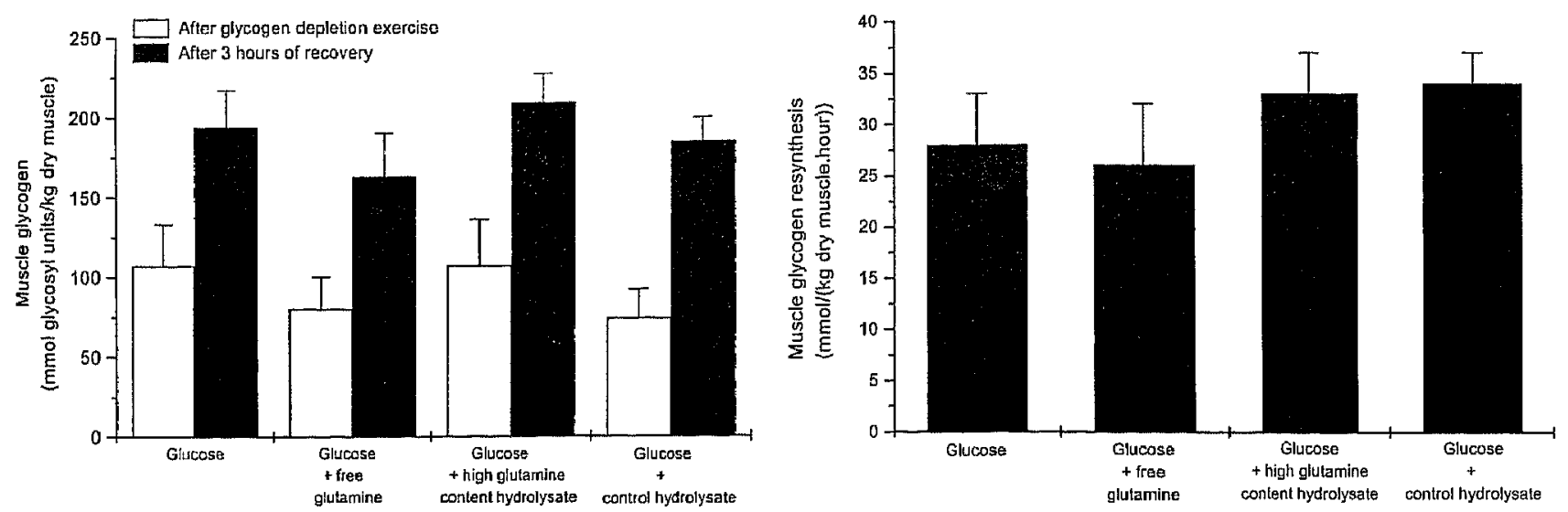

Fig. 2 Muscle glycogen content and rate of muscle glycogen resynthesis during recovery from intense cycle exercise. Values are means $\pm 5 E M$ for 8 subjects.

Table 1 Glycogen synthase activity after 3 h of recovery from intense exercise with ingestion of glucose or with the additives free glutamine, a high glutamine content protein hydrolysate and a control hydrolysate

\begin{tabular}{lllll}
\hline $\begin{array}{l}\text { Glycogen synthase } \\
\text { activity } \\
\left(\mu \mathrm{mol} \times \mathrm{g}^{-1} \times \mathrm{min}^{-1}\right)\end{array}$ & & $\begin{array}{l}\text { Total } \\
\text { activity }\end{array}$ & $\begin{array}{l}\text { Actual } \\
\text { activity }\end{array}$ & \% active \\
\hline Glucose & post-ex & $2.4 \pm 0.2$ & $1.6 \pm 0.1$ & $68 \pm 1$ \\
& $3 \mathrm{~h}$ & $2.1 \pm 0.3$ & $1.5 \pm 0.2$ & $72 \pm 2$ \\
Glucose + & post-ex & $1.9 \pm 0.2$ & $1.3 \pm 0.2$ & $68 \pm 2$ \\
free glutamine & $3 \mathrm{~h}$ & $2.4 \pm 0.1$ & $1.8 \pm 0.1$ & $73 \pm 3$ \\
Glucose + & post-ex & $2.4 \pm 0.2$ & $1.7 \pm 0.1$ & $71 \pm 2$ \\
gln hydrolysate & $3 \mathrm{~h}$ & $2.4 \pm 0.2$ & $1.8 \pm 0.2$ & $77 \pm 2$ \\
Glucose + & post-ex & $2.1 \pm 0.2$ & $1.4 \pm 0.2$ & $70 \pm 4$ \\
contr hydrolysate & $3 \mathrm{~h}$ & $2.6 \pm 0.4$ & $1.7 \pm 0.2$ & $72 \pm 5$ \\
\hline
\end{tabular}

Values are means \pm SEM for 8 subjects.

bout and after 3 hours of recovery. No differences were observed between the drinks (Table $\mathbf{1}$ ).

\section{Discussion}

A major finding of this study is that we, in contrast to a previous study $[27,8]$, did not find an effect of glutamine on the rate of glycogen resynthesis following exercise, despite a doubling of the plasma glutamine concentration after oral ingestion of the glutamine containing drink. A major difference is that we measured glycogen synthesis rates after oral ingestion of a glucose/free glutamine mixture, while Varnier and colleagues [27] infused glutamine only and measured very low glycogen synthesis rates far from maximal in the absence of glucose ingestion or infusion. Furthermore, we can conclude from our data that the intake of excessive amounts of glutamine and a doubling of the plasma glutamine concentration does not lead to increased glycogen synthase activities in muscle in vivo as previously observed in rat muscle in vitro [23]. A puzzling observation in this study is that the plasma glutamine concentration was not higher after ingestion of the hydrolysate with the high glutamine content compared to the normal glutamine content hydrolysate while the glutamine content of the former was nearly 4-fold higher: A possible explanation for this observation is that glutamine is an important fuel for the gut [26], and the additional glutamine in the hydrolysate with the high glutamine content may have been oxidised and not appeared in the main circulation. Several explanations may be given for the fact that free glutamine gave a much higher increase in plasma glutamine than the peptide bound glutamine. The most important are: 1) The amount of glutamine given was 4fold greater and may have exceeded the maximal capacity of the splanchnic area to extract and metabolise glutamine $[5,18] ; 2)$ The hydrolysate contains all amino acids, and thus the rate of protein synthesis may have been enhanced and part of the glutamine may have been incorporated in gut and liver protein. In case of only glutamine ingestion potentially protein synthesis is not enhanced as the other amino acids are lacking resulting in a lower incorporation of glutamine in protein and therefore a highel plasma glutamine concentration.

Insulin is an activator of muscle glycogen synthesis because of its stimulating effect on glucose transport and glycogen synthase activity $[12,14]$. The latter enzyme is the rate limiting enzyme in the glycogen synthesis pathway. Pancreatic insulin secretion is primarily regulated by blood glucose concentration, but protein ingestion also has been shown to stimulate insulin secretion in vivo $[19,20]$. Intravenous infusion of several essential amino acids also increases plasma insulin concentrations in vivo [7-9]. Some of these amino acids exert a synergistic effect when infused in combination with glucose [8]. Several amino acids also have been shown to stimulate insulin release in vitro by pancreatic $\beta$-cells $[11,24]$. Glutamine has been shown to have a permissive effect in vitro in that it may enhance the insulinotropic effect of other amino acids without having an effect on its own $[24,25]$.

In this study ingestion of the protein hydrolysates also caused a doubling of the insulin concentration during most of the recovery period, and although differences were not significant, the rates of glycogen resynthesis were appoximately $20 \%$ higher compared to ingestion of glucose only. We did not observe higher insulin concentrations following the ingestion of the peptide with the high glutamine content than following ingestion of the peptide with the normal glutamine content, nor 
an increase of the insulin concentration following ingestion of the drink with free glutamine. This suggests that the permissive effect of glutamine observed in vitro $[24,25]$ is not seen in vivo, probably because ample glutamine is around in vivo.

After $3 \mathrm{~h}$ of recovery we did not observe differences in plasma insulin concentration between the four drinks. This in fact may be the reason that glycogen synthase activity was also not different. However, since insulin concentration was higher during most of the recovery period after ingestion of both protein hydrolysates, glycogen synthase activity may also have been higher during most of the recovery period and, therefore, may have caused a higher mean glycogen synthesis rate. Zawadzki et al. [28] found a significant increase in the rate of glycogen synthesis during 4 hours of recovery when carbohydrates and intact protein were ingested compared to carbohydrates alone and attributed this effect to the higher insulin response with protein ingestion. Although the differences were not significant in this study, we therefore appear to confirm most of the data of Zawadzki et al. [28]. Burke et al. [3] were not able to find a positive effect on net glycogen accumulation or insulin concentration 24 hour after exercise with carbohydrate, protein and fat ingestion in the recovery period compared to carbohydrates alone. However, Burke et al. [3] did not sample in the early period where effects are expected to be larger. Muscle glycogen has been suggested to regulate its own synthesis. Negative feedback may reduce the glycogen synthesis rate and lead to a similar glycogen concentration after $24 \mathrm{~h}$, despite early differences between treatments.

As indicated in the introduction Tour de France cyclists and other athletes exercising for a long time at relative high intensity often have no more than $14-16 \mathrm{~h}$ between exercise bouts on subsequent days. Within that period they may have to replenish $100 \mathrm{mmol}$ of glucosyl units $\times \mathrm{kg}^{-1}$ wet weight muscle. With the glycogen resynthesis rates measured in the control treatment (Fig. 2) it takes $16-20 \mathrm{~h}$ to reach full glycogen stores, with the hydrolysates only $12-16 \mathrm{~h}$. This implies that with only carbohydrate supplementation the muscle glycogen stores may not be completely restored. Although we failed to find significant differences between the treatments, the approximately $20 \%$ higher glycogen resynthesis rates with protein hydrolysate ingestion may thus be important in sport practice. Therefore, further research is needed to definitively establish the existence of an enhancing effect of protein or protein hydrolysates on the rate of glycogen resynthesis and to investigate the optimal ratio between carbohydrate and protein intake for maximal glycogen resynthesis rates.

In conclusion, ingestion of free glutamine did not increase the rate of glycogen resynthesis in the $3 \mathrm{~h}$ recovery period following intermittent high intensity exercise despite a massive increase in the plasma glutamine concentration. Furthermore, this increase in plasma glutamine concentration did not increase glycogen synthase activity in vivo $3 \mathrm{~h}$ post-exercise. Ingestion of a hydrolysate with a high glutamine content did not increase plasma glutamine concentration compared to a hydrolysate with a normal glutamine content despite a 4-fold higher glutamine content. Both protein hydrolysates prevented the decrease in plasma glutamine concentration during recovery from intense exercise. Both protein hydrolysates increased the rate of glycogen resynthesis during recovery most likely via a stimulating effect on insulin secretion, but the dif- ference was not statistically significant implying that further research is needed to definitively establish the existence of the protein effect and its potential relevance for sports practice.

\section{Acknowledgements}

This research was supported by a grant from Quest International (Bussum, The Netherlands).

\section{References}

${ }^{1}$ Baquet $A$, Hue L. Swelling of rat hepatocytes stimulates glycogen synthesis. J Biol Chem 1990; 265: 955-959

${ }^{2}$ Bergström J, Hermansen L, Hultman E, Saltin B. Diet, muscle glycogen and physical performance. Acta Physiol Scand 1967; 71 : $1140-1150$

${ }^{3}$ Burke LM, Collier GR, Beasiey SK, Davis PG, Fricker PA, Heeley P, Walder $\mathrm{K}$, Hargreaves M. Effect of coingestion of fat and protein with carbohydrate feeding on muscle glycogen storage. J Appl Physiol 1995; 78: 2187-2192

${ }^{4}$ Danforth WH. Glycogen synthase activity in skeletal muscle-Intervention of two forms and control glycogen synthesis. J Biol Chem 1965: 240: 588 -593

${ }^{5}$ Déchelotte P, Darmaun D, Rongier M, Hecketsweiler B, Rigal O, Desjeux J-F. Absorption and metabolic effects of enterally administered glutamine in humans. Am J Physiol 1991; 260: G677G682

${ }^{6}$ Elia M, Shlatmann A, Goren A, Austin S. Amino acid metabolism in muscle and in the whole body of man before and after ingestion of a single mixed meal. Am J Clin Nutr 1989; 49: 1203-1210

7 Floyd JC, Fajans SS, Conn JW, Knopf RF, Rull J. Stimulation of insulin secretion by amino acids. J Clin Invest 1966; 45; 1487-1502

${ }^{8}$ Floyd JS, Fajans SS, Pek CA, Thiffault CA, Knopf RF, Conn JW. Synergistic effect of essential amino acids and glucose upon insulin secretion in man. Diabetes 1970; 19: 109- 115

${ }^{9}$ Floyd JS, Fajans SS, Pek CA, Thiffault CA, Knopf RF, Conn JW. Synergistic effect of certain amino acid pairs upon insulin secretion in man. Diabetes 1970; 19: 102-108

${ }^{10}$ Häussinger $D$, Lang $F$, Gerok W. Regulation of cell function by the cellular hydration state. Am J Physiol 1994; 267: E343-E355

$"$ Hutton JC, Sener A, Malaisse WJ. Interaction of branched chain amino acids and keto acids upon pancreatic islet metabolism and insulin secretion. J Biol Chem 1980; 255: $7340-7346$

${ }^{12}$ Ivy JL, Holloszy JO. Persistent increase in glucose uptake by rat skeletal muscle following exercise. Am J Physiol 1981; 241: $\mathrm{C} 200-\mathrm{C} 203$

${ }^{13}$ Ivy JL, Lee MC, Brozinick JT, Reed MJ. Muscle glycogen storage after different amounts of carbohydrate ingestion. J Appl Physiol 1988; $65: 2018-2033$

14 James $D E$, Jenkins $A B$, Kreager EW. Heterogeneity of insulin action in individual muscles in vivo: euglycemic clamp studies in rats. Am J Physiol 1985; 248: E567 -E574

${ }^{15}$ Kuipers H, Keizer HA, Brouns F, Saris WHM. Carbohydrate feeding and glycogen synthesis during exercise in man. Pflügers Archives $1987 ; 410 ; 652-656$

${ }^{16}$ Lavoinne A, Baquet A, Hue L. Stimulation of glycogen synthesis and lipogenesis by glutamine in isolated rat hepatocytes. Biochem J 1987; 248: $429-437$

${ }^{17}$ Lund P. UV-method with glutaminase and glutamate dehydrogenase. In: Bergmeyer (ed). Methods in enzymatic analysis. $3^{\text {rd }}$ edition, volume VIII. Weinheim: VCH Publishers, 1990: 357-363

${ }^{18}$ Matthews DE, Marano MA, Campbell RG. Splanchnic bed utilization of glutamine and glutamic acid in humans. Am J Physiol 1993; 264: E848-E854 
${ }^{19}$ Nuttal FQ Mooradian AD, Gannon MC, Billington C, Krezowsk P. Effect of protein ingestion on the glucose and insulin response to a standardized oral glucose load. Diabetes Care 1984; 7:465-470

${ }^{20}$ Rabinowitz D, Merimee TJ, Maffezzol R, Burgess JA. Patterns of hormonal release after glucose, protein, and glucose plus protein. Lancet 1966; 2: 454-456

${ }^{21}$ Reed MJ, Brozinick JT, Lee MC, Ivy JL. Muscle glycogen storage post exercise: effect of mode of carbohydrate administration. J Appl Physiol 1989; 66: 720-726

22 Romijn JA, Coyle EF, Sidossis LS, Gastaldelii A, Horowitz JF, Endert E, Wolfe RR. Regulation of endogenous fat and carbohydrate metabolism in relation to exercise intensity and duration. Am J Physiol 1993; 265: E380-E391

${ }^{23}$ Scislowski PWD, Niblock A, Lindsay Y, Weryk B, Watt PW, Rennie $\mathrm{M}$. Glutamine stimulates glycogen synthesis in skeletal muscle. Clin Nutr 1989; Suppl 8: 97

${ }^{24}$ Sener A, Hutton JC, Malaisse WJ. The stimulus secretion coupling of amino acid-induced insulin release synergistic effects of L-glutamine and 2-keto acids upon insulin secretion. Biochem Biophys Acta 1981; 677: $32-38$

${ }^{25}$ Sener A, Malaisse WJ. L-Leucine and a non metabolized analogue activate pancreatic islet glutamate dehydrogenase. Nature 1980; 288: $187-189$

${ }^{26}$ Souba WW, Austgen TR. Interorgan glutamine flow following surgery and infection. JPEN 1990; 14: 90S-93S

27 Varnier M, Leese GP. Thompson J, Rennie MJ. Stimulatory effect of glutamine on glycogen accumulation in human skeletal muscle. Am J Physiol 1995; 269: E309-E315

${ }^{28}$ Zawadzki KM, Yaspelkis BB III, Ivy JL. Carbohydrate-protein complex increases the rate of muscle glycogen storage after exercise. J Appl Physiol 1992; 72: $1854-1859$

\section{Corresponding Author:}

\section{G. van Hall}

Copenhagen Muscle Research Centre

Rigshospitalet section 7652

20 Tagensvej

DK-2200 Copenhagen $N$

Denmark

Phone: $+45-35457621$

Fax: $\quad+45-3545-7634$

E-mail: RH01769@RH.DK 